Ophthalmologica 1946;112:55-56

\title{
Johannes Iseli zum 70. Geburtstag
}

Am 1. August dieses Jahres wird Johannes Iseli siebzig Jahre alt. Es ist geboten, daß auch an dieser Stel·le des vortrefflichen Mitarbeiters einer großen Zahl von Medizinern, insbesondere von Ophthalmologen, gedacht wird.

S. Sein Vater war protestantischer Prediger und kehrte nachdem er in Oesterreich gelebt hatte wo auch unser Jubilar in Innsbruck geboren wurde, 